\title{
Purification and Regulation of a Cloned Thiobacillus ferrooxidans Glutamine Synthetase
}

\author{
By MARIA EUGENIA C. BARROS, DOUGLAS E. RAWLINGS \\ AND DAVID R. WOODS* \\ Department of Microbiology, University of Cape Town, Rondebosch 7700, South Africa
}

(Received 19 September 1985; revised 4 February 1986)

\begin{abstract}
Glutamine synthetase (GS) (EC 6.3.1.2) was purified from an Escherichia coli glnA deletion strain containing the Thiobacillus ferrooxidans GS structural gene. The apparent $M_{\mathrm{r}}$ of the cloned $T$. ferrooxidans GS subunit was approximately 60000 . This indicates a particle $M_{\mathrm{r}}$ for the undissociated enzyme of 720000 , assuming the enzyme is the typical dodecamer. Electron microscopy of purified GS revealed characteristic disc shaped molecules with central holes. The cloned $T$. ferrooxidans $\mathrm{GS}$ was regulated by $\mathrm{Mg}^{2+}$ or $\mathrm{Mn}^{2+}$, adenylylation, and nitrogen source but was not affected by feedback modifiers. The GS has a $\gamma$-glutamyltransferase isoactivity point of $\mathrm{pH} 7 \cdot 71$.
\end{abstract}

\section{INTRODUCTION}

In the nitrogen metabolism of bacteria, glutamine synthetase (GS) (EC 6.3.1.2) plays a central role, as it catalyses one of the main reactions by which ammonia is assimilated (Tyler, 1978):

$$
\text { L-glutamate }+\mathrm{NH}_{4}^{+}+\mathrm{ATP} \rightarrow \text { L-glutamine }+\mathrm{ADP}+\mathrm{P}_{\mathrm{i}}
$$

No studies have been made of GS in strains of the acidophilic autotroph Thiobacillus ferrooxidans. $T$. ferrooxidans is the most important bacterium in the leaching of metals from mineral ores, and as the scarcity of nitrogen in leach liquors may limit the efficiency of bacterial leaching operations (Tuovinen et al., 1979), it is important that the enzymes involved in nitrogen metabolism be studied. Investigations on intracellular enzymes in T. ferrooxidans are hampered, as it is an obligate autotroph, and high yields of cells are difficult to obtain. To overcome this problem we cloned the $T$. ferrooxidans GS structural gene $g \ln A$, and nitrogen regulatory genes which complement the $n t r B$ and $n t r C$ gene functions in Escherichia coli (Barros et al., 1985). We describe here the purificaton and characterization of cloned $T$. ferrooxidans GS produced in $E$. coli.

\section{METHODS}

Bacterium and growth conditions. The $E$. coli $g \ln A, n \operatorname{tr} B, n \operatorname{tr} C$ deletion strain ET8051, which harboured the recombinant plasmid pMEB 100 containing the $T$. ferrooxidans $g \ln A$ gene and genes which complement the ntr $B$ and $n t r C$ gene functions (Barros et al., 1985), was used for the production of GS. E. coli ET8051(pMEB100) was grown and maintained in glucose minimal medium containing $\left(\mathrm{NH}_{4}\right)_{2} \mathrm{SO}_{4}$ as the sole nitrogen source. In experiments where alternative carbon and nitrogen sources were required, glucose and $\left(\mathrm{NH}_{4}\right)_{2} \mathrm{SO}_{4}$, respectively, were replaced by the alternative compounds.

Preparation of cell extracts. All extraction and purification steps were done at 0 to $4^{\circ} \mathrm{C}$ with the exception of the heat treatments. For the purification of GS, washed E. coli ET8051(pMEB100) cells from 400 ml cultures $\left(\mathrm{OD}_{600}\right.$ 0.9 ) were resuspended in $20 \mathrm{ml} \mathrm{SB}$ buffer (20 mM-imidazole, $10 \mathrm{mM}-\mathrm{MgCl}_{2}, 2 \mathrm{~mm}-2$-mercaptoethanol, $\mathrm{pH} 7.5$ )

Abbreviations: GS, glutamine synthetase; $\gamma \mathrm{GT}, \gamma$-glutamyl transferase; SVP, snake venom phosphodiesterase. 
(approximately $0.19 \mathrm{~g}$ wet weight $\mathrm{ml}^{-1}$ ). The cells were disrupted by two passages through a Yeda Press (Yeda Scientific Instruments, Rehovot, Israel). The preparation was then sonicated and the cell debris removed by centrifugation at $16000 \mathrm{~g}$ for $1 \mathrm{~h}$. For the experiments on the regulation of GS activity, samples of exponentialphase $E$. coli ET8051 (pMEB100) cultures were washed and resuspended in SB buffer. After sonication at $4^{\circ} \mathrm{C}$ the cell debris was removed by centrifugation at $16000 \mathrm{~g}$ for $40 \mathrm{~min}$ at $4{ }^{\circ} \mathrm{C}$ and the cell extracts were assayed for GS activity.

GS assays. GS activity was measured by the $\gamma$-glutamyltransferase ( $\gamma \mathrm{GT}$ ) assay (total GS activity) of Bender $e t$ al. (1977) and by the biosynthetic assay of Shapiro \& Stadtman (1970). In the biosynthetic assay one unit of GS activity is defined as the amount of enzyme required to form $1 \mu \mathrm{mol} P_{\mathrm{i}} \mathrm{min}^{-1}$. Protein was determined by the Lowry procedure.

Purification of cloned T. ferrooxidans GS. GS was purified by the method of Streicher \& Tyler (1980). The crude extract $(20 \mathrm{ml})$ was centrifuged at $100000 \mathrm{~g}$ for $1 \mathrm{~h}$ and the supernatant (fraction $\mathrm{S}_{1}$ ) was re-centrifuged at $100000 \mathrm{~g}$ for $2 \mathrm{~h}$ and the pellet resuspended in $2 \mathrm{ml} \mathrm{SB}$ buffer (fraction $\mathrm{P}_{1}$ ). The $\mathrm{P}_{1}$ preparation was kept at $4{ }^{\circ} \mathrm{C}$ for $18-24 \mathrm{~h}$ and then centrifuged at $12000 \mathrm{~g}$ for $15 \mathrm{~min}$. The supernatant was centrifuged at $100000 \mathrm{~g}$ for $2 \mathrm{~h}$ and the pellet resuspended in $2 \mathrm{ml} \mathrm{SB}$ buffer (fraction $\mathrm{P}_{2}$ ). The $\mathrm{P}_{2}$ fraction was heated at $55^{\circ} \mathrm{C}$ for $10 \mathrm{~min}$ and then cooled in an ice bath. Denatured proteins were removed by centrifugation at $12000 \mathrm{~g}$ for $15 \mathrm{~min}$ to yield the supernatant fraction $\mathbf{S}_{2}$.

Polyacrylamide gel electrophoresis ( $P A G E$ ). The fractions obtained during the purification of GS were subjected to SDS- $10 \%(w / v)$ PAGE according to the methods of Laemmli (1970) and O'Farrell (1975).

Electron microscopy. Purified GS from E. coli ET8051(pMEB100) was fixed with $3 \%(\mathrm{w} / \mathrm{v})$ glutaraldehyde, stained with $2 \%(w / v)$ uranyl acetate and observed with a Zeiss EM109 electron microscope.

Snake venom phosphodiesterase (SVP) digestion of the purified GS. This was done by the method of Shapiro et al. (1967).

\section{RESULTS}

\section{Purification and characterization of cloned T. ferrooxidans GS}

The cloned $T$. ferrooxidans GS produced in E. coli ET8051 by pMEB100 was purified sevenfold with a $24 \%$ recovery and a high specific activity (Table 1 ). SDS-PAGE of the purified GS showed two bands with slightly different mobilities (Fig. 1). The top band is characteristic of unadenylylated GS subunits, and the lower band, with slightly higher mobility, is characteristic of adenylylated GS subunits (Lei et al., 1979). The apparent $M_{\mathrm{r}}$ of the unadenylylated GS subunit was approximately 60000 (Fig. 1).

The structure of the purified GS was investigated by electron microscopy (Fig. 2). In some of the molecules a central hole was visible; this is characteristic of the dodecameric assembly of the GS subunits from other bacteria (Frey et al., 1975).

Cloned $T$. ferrooxidans GS purified from $E$. coli ET8051 and partially purified GS from Vibrio alginolyticus and $E$. coli were electroblotted (Towbin et al., 1979) from polyacrylamide gels onto nitrocellulose filters. $V$. alginolyticus GS antiserum reacted positively with the cloned $T$. ferrooxidans GS and $E$. coli GS, which provided evidence for the structural similarity between the different GS enzymes. The band obtained for the cloned T. ferrooxidans GS was between the bands corresponding to the GS from E. coli and V. alginolyticus, which is in agreement with the subunit $M_{\mathrm{r}}$ values of the GS from these three bacteria (Stadtman \& Ginsburg, 1974; Bodasing $e t$ al., 1985).

\section{Table 1. Purification of cloned T. ferrooxidans GS from E. coli ET8051(pMEB100)}

GS activity was determined by the $\gamma \mathrm{GT}$ assay. The details of the purification procedures and the fractions $S_{1}, P_{1}, P_{2}$ and $S_{2}$ are described in Methods.

\begin{tabular}{|c|c|c|c|c|c|}
\hline Fraction & $\begin{array}{l}\text { Vol. } \\
\text { (ml) }\end{array}$ & $\begin{array}{c}\text { GS specific activity } \\
{[\mu \mathrm{mol} \gamma \text {-glutamyl hydroxamate }} \\
\left.(\mathrm{mg} \text { protein })^{-1} \mathrm{~min}^{-1}\right]\end{array}$ & $\begin{array}{l}\text { Total } \\
\text { protein } \\
\text { (mg) }\end{array}$ & $\begin{array}{c}\text { Fold } \\
\text { purification }\end{array}$ & $\begin{array}{c}\text { Recovery } \\
(\%)\end{array}$ \\
\hline $\begin{array}{l}\text { Crude extract } \\
\qquad \begin{array}{c}\mathrm{S}_{1} \\
\mathrm{P}_{1} \\
\mathrm{P}_{2} \\
\mathrm{~S}_{2}\end{array}\end{array}$ & $\begin{array}{r}20 \\
20 \\
2 \\
2 \\
2\end{array}$ & $\begin{array}{r}12 \cdot 54 \\
8 \cdot 76 \\
29 \cdot 35 \\
60 \cdot 02 \\
88 \cdot 08\end{array}$ & $\begin{array}{r}80 \cdot 0 \\
76 \cdot 7 \\
25 \cdot 0 \\
5 \cdot 2 \\
2 \cdot 7\end{array}$ & $\begin{array}{l}1 \\
0 \cdot 7 \\
2 \\
5 \\
7\end{array}$ & $\begin{array}{r}100 \\
67 \\
73 \\
31 \\
24\end{array}$ \\
\hline
\end{tabular}




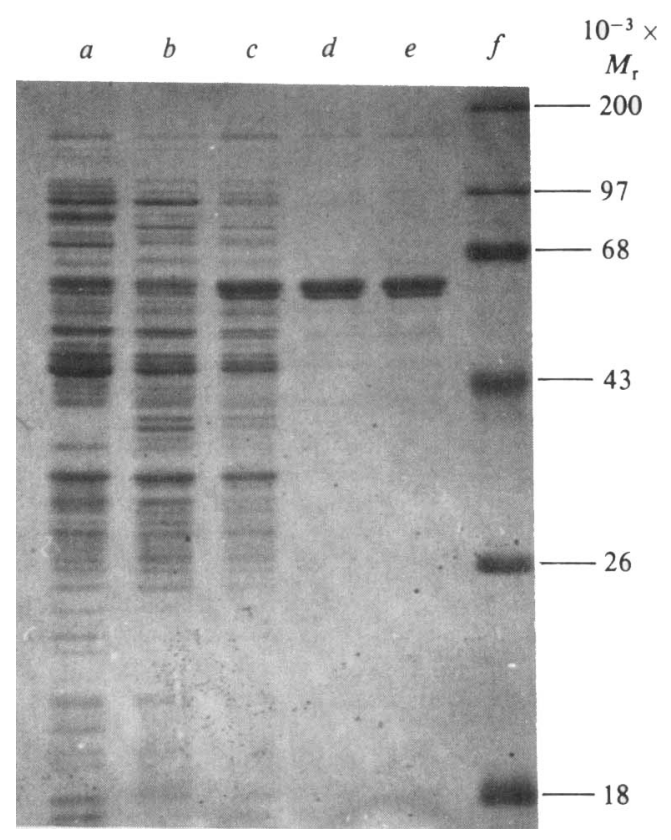

Fig. 1. SDS-PAGE of crude and purified preparations of cloned $T$. ferrooxidans GS. Lane $a$, crude extract; lane $b, \mathrm{~S}_{1}$ fraction; lane $c, \mathrm{P}_{1}$ fraction; lane $d, \mathrm{P}_{2}$ fraction; lane $e, \mathrm{~S}_{2}$ fraction; lane $f, M_{\mathrm{r}}$ markers. Details of the purification procedure are given in Methods. Protein concentrations applied per lane were: lanes $a, b$ and $c, 45 \mu \mathrm{g}$; lanes $d$ and $e, 15 \mu \mathrm{g}$; lane $f, 30 \mu \mathrm{g}$.

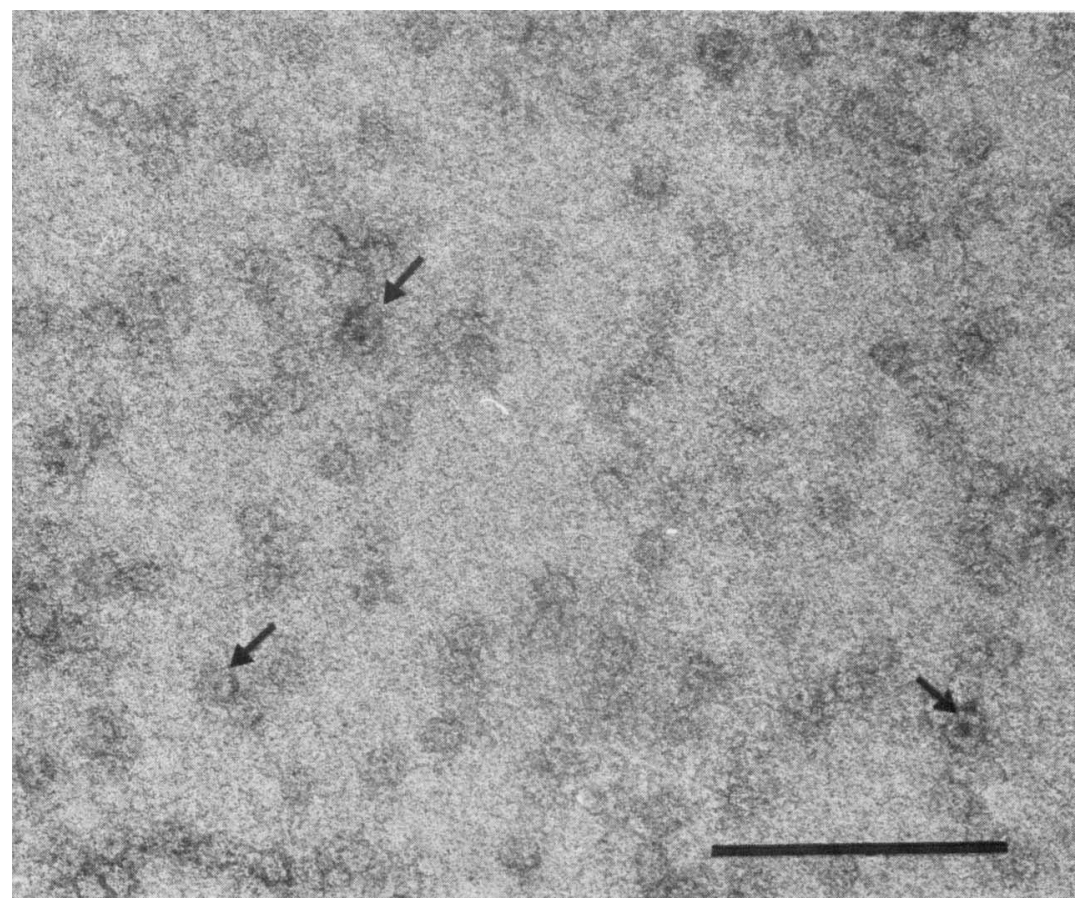

Fig. 2. Electron micrograph of purified cloned T. ferrooxidans GS. Bar, $0.01 \mu \mathrm{m}$. 


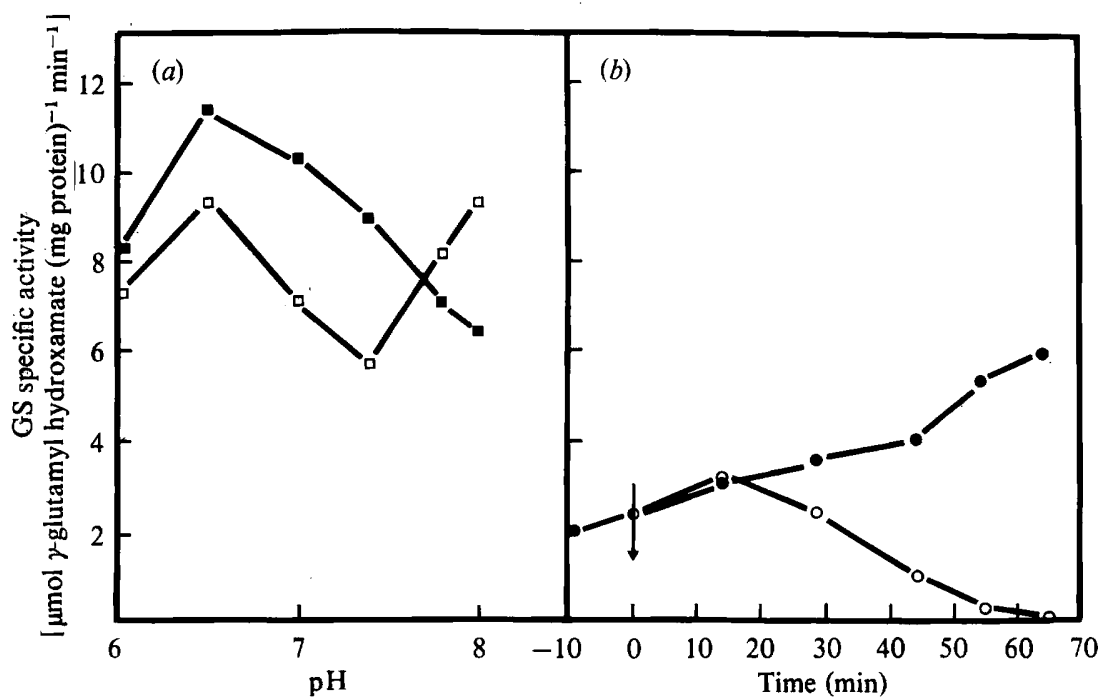

Fig. 3. GS activity from $\mathrm{NH}_{4}^{+}$-shocked $\left(15 \mathrm{~mm}-\mathrm{NH}_{4}^{+}\right)(\square, \mathrm{O})$ and unshocked $(\square, 0)$ exponential phase $E$. coli ET8051 (pMEB100) cells. (a) Effect of pH on $\gamma$ GT activity. Cells were $\mathrm{NH}_{4}^{+}$-shocked 7 min before harvesting. (b) Deadenylylated $\gamma \mathrm{GT}$ activity determined by the $\gamma \mathrm{GT}$ assay in the presence of 60 mM- $\mathrm{MgCl}_{2}$. The arrow indicates the time of $\mathrm{NH}_{4}^{+}$shocking. SEM were $<5 \%$ of the values shown.

\section{$\mathrm{NH}_{4}^{+}$-shocking and isoactivity point determinations}

Evidence that the cloned $T$. ferrooxidans GS isolated from $E$. coli contained adenylylated subunits was obtained from SVP digestion and the biosynthetic assay in the presence of $\mathrm{Mg}^{2+}$ and $\mathrm{Mn}^{2+}$. Purified GS assayed in the presence of $\mathrm{Mg}^{2+}$ and $\mathrm{Mn}^{2+}$ showed an activity of 0.68 and 8.26 units (mg protein) $)^{-1}$, respectively. After treatment of this enzyme preparation with SVP, which released all the AMP from the GS, the $\mathrm{Mg}^{2+}$-dependent activity increased to 8.26 units (mg protein) ${ }^{-1}$, while the $\mathrm{Mn}^{2+}$-dependent activity decreased to 0 units (mg protein $)^{-1}$.

Since adenylylated and deadenylylated GS from some bacteria have been shown to exhibit different $\mathrm{pH}$ response curves (Bender et al., 1977), the isoactivity point at which both forms of the enzyme have the same activity was determined for cloned $T$. ferrooxidans GS. Exponential phase cells of $E$. coli ET8051(pMEB100) in glucose minimal medium were 'shocked' by the addition of $\left(\mathrm{NH}_{4}\right)_{2} \mathrm{SO}_{4}(15 \mathrm{mM})$ and harvested $7 \mathrm{~min}$ later. Crude cell extracts from shocked and unshocked cultures were assayed for $\gamma \mathrm{GT}$ activity between $\mathrm{pH} 6.0$ and 8.0 (Fig. $3 a$ ). The isoactivity point was at $\mathrm{pH} 7.71$ (Fig. $3 a$ ).

Further evidence that the cloned $T$. ferrooxidans GS contained adenylylated and deadenylylated subunits was obtained by assaying the deadenylylated form of $\mathrm{GS}\left(\mathrm{Mg}^{2+}\right.$ dependent) after shocking a growing culture of $E$. coli ET8051(pMEB100) with 15 mM$\left(\mathrm{NH}_{4}\right)_{2} \mathrm{SO}_{4}$ (Fig. $3 b$ ). $\mathrm{Mg}^{2+}$-dependent $\gamma \mathrm{GT}$ activity decreased to zero $65 \mathrm{~min}$ after the addition of $\left(\mathrm{NH}_{4}\right)_{2} \mathrm{SO}_{4}$.

\section{Effect of nitrogen source on GS activity}

High $\gamma$ GT specific activity of cloned $T$. ferrooxidans GS [approximately $30 \mu \mathrm{mol} \gamma$-glutamyl hydroxamate $(\mathrm{mg} \text { protein })^{-1} \mathrm{~min}^{-1}$ ] was obtained at low concentrations of $\left(\mathrm{NH}_{4}\right)_{2} \mathrm{SO}_{4}(0.75$ $\mathrm{mM})$, whereas at concentrations of 6 to $45 \mathrm{~mm}-\left(\mathrm{NH}_{4}\right)_{2} \mathrm{SO}_{4}$, lower $\gamma \mathrm{GT}$ specific activities were obtained [approximately 9 to $11 \mu \mathrm{mol} \gamma$-glutamyl hydroxamate (mg protein) ${ }^{-1} \mathrm{~min}^{-1}$ ].

The nature of the nitrogen source affected cloned $T$. ferrooxidans GS activity in $E$. coli (Table 2). Growth with proline as the sole nitrogen source markedly enhanced GS activity, whereas GS activity was repressed over $90 \%$ by growth with histidine and arginine. 
Table 2. Effect of nitrogen source for growth of E. coli on the activity of the cloned

$$
T \text {. ferrooxidans } G S \text { enzyme }
$$

E. coli ET8051(pMEB100) was grown in succinate minimal medium containing various nitrogen compounds. GS specific activities of mid-exponential phase cells was determined by the $\gamma \mathrm{GT}$ assay. The results are expressed as percentages of the activity in cells grown in succinate minimal medium containing $7.5 \mathrm{~mm}-\left(\mathrm{NH}_{4}\right)_{2} \mathrm{SO}_{4}$, which was $12.54 \mu \mathrm{mol} \gamma$-glutamyl hydroxamate (mg protein) ${ }^{-1} \mathrm{~min}^{-1}$. The values are means of three determinations; SEM were 5 to $10 \%$ of the values shown.

$\begin{array}{lcc}\begin{array}{c}\text { Nitrogen } \\ \text { source }\end{array} & \begin{array}{c}\text { Concn } \\ (\mathrm{mM})\end{array} & \begin{array}{c}\text { GS activity } \\ (\%)\end{array} \\ \left(\mathrm{NH}_{4}\right)_{2} \mathrm{SO}_{4} & 7 \cdot 5 & 100 \\ \text { Proline } & 43 & 253 \\ \text { Histidine } & 23 & 6 \\ \text { Arginine } & 24 & 4 \\ \text { Glutamine } & 34 & 94 \\ \text { Glutamate } & 34 & 73\end{array}$

\section{Catabolite repression of GS activity}

The addition of glucose or fructose (27 mM) to exponential E. coli ET8051(pMEB100) cultures in succinate minimal medium repressed the level of cloned $T$. ferrooxidans GS activity by $20-30 \%$.

\section{Effect of feedback modifiers on cloned $T$. ferrooxidans $G S$}

This was determined in crude extracts prepared from cells grown in glucose minimal medium. The feedback modifiers were added to the $\gamma$ GT substrate solution before the addition of the crude extract. The $\gamma \mathrm{GT}$ activity of cell-free cloned $T$. ferrooxidans $\mathrm{GS}$ was not affected by proline $(43 \mathrm{mM})$, histidine (24 mM), arginine (24 mM), glutamate (34 mM), AMP (35 mM) and $\left(\mathrm{NH}_{4}\right)_{2} \mathrm{SO}_{4}$ (38 mM).

\section{DISCUSSION}

The cloned $T$. ferrooxidans GS subunit has an apparent $M_{\mathrm{r}}$ of approximately 60000 . Assuming that the enzyme is a typical dodecamer, the particle $M_{\mathrm{r}}$ for the undissociated GS would be approximately 720000 . The estimated $M_{\mathrm{r}}$ of the cloned $T$. ferrooxidans GS is higher than that for E. coli, Bacillus subtilis, Bacillus stearothermophilus and 'Bacillus caldolyticus', which have subunits of $M_{\mathrm{r}} 56000,50000,51000$ and 51000 respectively (Stadtman \& Ginsburg, 1974; Deuel et al., 1970; Wedler \& Hoffmann, 1974; Wedler et al., 1980). However, the cloned $T$. ferrooxidans GS has a similar $M_{\mathrm{r}}$ to those of Bradyrhizobium japonicum and $V$. alginolyticus, which have an estimated particle $M_{\mathrm{r}}$ of 720000 and 744000 respectively and are composed of subunits of $M_{\mathrm{r}} 60000$ and 62000 respectively (Bhandari et al., 1983; Bodasing et al., 1985).

The cross-reactivity obtained between the antiserum prepared against $V$. alginolyticus GS and both cloned GS from $T$. ferrooxidans and $E$. coli GS extends the finding that GSs from heterotrophic Gram-negative bacteria are related (Tronick et al., 1973). This study shows that the antigenic relatedness between the GSs of Gram-negative bacteria holds even for an autotrophic chemolithotroph such as $T$. ferrooxidans.

Previously we reported that no homology could be detected between either cloned or chromosomal GS DNA from E. coli and cloned GS from T. ferrooxidans (Barros et al., 1985). In spite of this lack of homology at the DNA level the GSs from these two bacteria, as determined by both electron microscopy and antigenicity, are related. The GS DNA sequence, therefore, does not appear to be subject to the strong evolutionary constraints seen for the genes of the nitrogenase enzymes (Ruvkun \& Ausubel, 1980). The DNA sequence of the $T$. ferrooxidans GS gene should, therefore, provide an important contribution to an understanding of the preferred codon usage of the bacterium.

The $E$. coli GS has been shown to be regulated by at least four different mechanisms: by kinetic factors, including the concentration of the divalent cations $\mathrm{Mg}^{2+}$ or $\mathrm{Mn}^{2+}$, which are 
required for the structural stabilization of the enzyme; by covalent modification of the enzyme by adenylylation and deadenylylation; by repression and derepression of enzyme synthesis in response to the nitrogen source; and by cumulative feedback inhibition by various end-products of glutamine metabolism (Tyler, 1978; Brown, 1980). Cloned $T$. ferrooxidans GS activity in $E$. coli was regulated by $\mathrm{Mg}^{2+}$ or $\mathrm{Mn}^{2+}$, adenylylation, and nitrogen source, but was not affected by feedback modifiers which affect $E$. coli and other prokaryotic GSs (Bodasing et al., 1985). GS from Anabaena and Chloroflexus have also been reported to be resistant to most of the feedback inhibitors that affect many prokaryotic GSs (Kaulen \& Klemme, 1983).

Production of the cloned $T$. ferrooxidans GS in $E$. coli was relatively insensitive to regulation by glucose or fructose catabolite repression. Since $T$. ferrooxidans is an obligate autotroph and its growth is inhibited by traces of galactose in agar (Tuovinen \& Kelly, 1973), it is perhaps not surprising that the production of GS is not very sensitive to regulation by sugars.

We acknowledge research grants from the South African Council for Scientific and Industrial Research.

\section{REFERENCES}

Barros, M. E. C., Rawlings, D. E. \& Woods, D. R. (1985). Cloning and expression of the Thiobacillus ferrooxidans glutamine synthetase gene in Escherichia coli. Journal of Bacteriology 164, 1386-1389.

Bender, R. A., Janssen, K. A., Resnick, A. D., Blumenberg, M., Foor, F. \& Magasanik, B. (1977). Biochemical parameters of glutamine synthetase from Klebsiella aerogenes. Journal of Bacteriology 129, 1001-1009.

Bhandari, B., Vairinhos, F. \& Nicholas, D. J. D. (1983). Some properties of glutamine synthetase from Rhizobium japonicum CC705 and CC723. Archives of Microbiology 136, 84-88.

Bodasing, S. J., BRANDT, P. W., RobB, F. T. \& Woods, D. R. (1985). Purification and regulation of glutamine synthetase in a collagenolytic Vibrio alginolyticus strain. Archives of Microbiology 140, 369374.

BroWN, C. M. (1980). Ammonia assimilation and utilization in bacteria and fungi. In Microorganisms and Nitrogen Sources, pp. 511-535. Edited by J. W. Payne. New York: John Wiley \& Sons.

Deuel, T. F., Ginsburg, A., Yeh, J., Shelton, E. \& StadTMan, E. R. (1970). Bacillus subtilis glutamine synthetase. Journal of Biological Chemistry 245, 5195-5205.

Frey, T. G., EisenberG, D. \& Eiserling, F. A. (1975). Glutamine synthetase forms three- and sevenstranded helical cables. Proceedings of the National Academy of Sciences of the United States of America 72, 3402-3406.

Kaulen, H. \& Klemme, J. H. (1983). No evidence of covalent modification of glutamine synthetase in the thermophilic phototrophic bacterium Chloroflexus aurantiacus. FEMS Microbiology Letters 20, 7579.

LAEMMLI, U. K. (1970). Cleavage of structural proteins during the assembly of the head of bacteriophage $T_{4}$. Nature, London 227, 680-685.

Lei, M., Aebi, U., Heidner, E. G. \& Eisenberg, D. (1979). Limited proteolysis of glutamine synthetase is inhibited by glutamate and by feedback inhibitors. Journal of Biological Chemistry 254, 3129-3134.

O'Farrell, P. H. (1975). High resolution two-dimen- sional electrophoresis of proteins. Journal of Biological Chemistry 250, 4007-4021.

Ruvkun, G. B. \& Ausubel, F. (1980). Interspecies homology of nitrogenase genes. Proceedings of the National Academy of Sciences of the United States of America 77, 191-195.

Shapiro, B. M. \& StadtMan, E. R. (1970). Glutamine synthetase (E. coli). Methods in Enzymology 17A, 910-922.

Shapiro, B. M., Kingdon, H. S. \& Stadtman, E. R. (1967). Regulation of glutamine synthetase: a new form of the enzyme with altered regulatory and kinetic properties. Proceedings of the National Academy of Sciences of the United States of America 58, 642-649.

Stadtman, E. R. \& Ginsburg, A. (1974). The glutamine synthetase of Escherichia coli: structure and control. In The Enzymes, 3rd edn, vol. 10, pp. 755-807. Edited by P. D. Boyer. New York \& London: Academic Press.

Streicher, S. L. \& Tyler, B. (1980). Purification of glutamine synthetase from a variety of bacteria. Journal of Bacteriology 142, 69-78.

Towbin, H., Staehelin, T. \& Gordon, J. (1979). Electrophoretic transfer of proteins from polyacrylamide gel to nitrocellulose sheets: procedure and some applications. Proceedings of the National Academy of Sciences of the United States of America 76, 4350-4354.

Tronick, S. R., Ciardi, J. E. \& Stadtman, E. R. (1973). Comparative biochemical and immunological studies of bacterial glutamine synthetases. Journal of Bacteriology 115, 858-868.

Tuovinen, O. H. \& Kelly, D. P. (1973). Studies on the growth of Thiobacillus ferrooxidans. I. Use of membrane filters and ferrous iron agar to determine viable numbers and comparison with ${ }^{14} \mathrm{CO}_{2}$-fixation and iron oxidation as measures of growth. Archives of Microbiology 88, 285-298.

Tuovinen, O. H., Panda, T. A. \& Tsuchiya, H. M. (1979). Nitrogen requirements of iron-oxidising Thiobacillus for acidic ferric sulphate regeneration. Applied and Environmental Microbiology 37, 954-958. TYLER, B. (1978). Regulation of the assimilation of 
nitrogen compounds. Annual Review of Biochemistry 47, 1127-1162.

WedleR, F. C. \& HoffmanN, F. M. (1974). Glutamine synthetase of Bacillus stearothermophilus. I. Purification and basic properties. Biochemistry 13, 32073214.
Wedler, F. C., Shreve, D. S., Kenney, R, M., Ashour, A. E., Carfi, J. \& Rhee, S. G. (1980). Two glutamine synthetases from Bacillus caldolyticus, an extreme thermophile. Journal of Biological Chemistry 255, 9507-9516. 